\title{
Treatment and results in pediatric traumatic hip dislocation: Case series and review of the literature
}

\author{
Serdar Hakan Başaran, M.D., ${ }^{1}$ Mustafa Gökhan Bilgili, M.D., ${ }^{2}$ Ersin Erçin, M.D., ${ }^{2}$ \\ Alkan Bayrak, M.D., ${ }^{2}$ Halil Nadir Öneş, M.D., ${ }^{2}$ Mustafa Cevdet Avkan, M.D. ${ }^{2}$ \\ ${ }^{1}$ Department of Orthopaedic and Traumatology, Karabük University Faculty of Medicine, Karabük; \\ ${ }^{2}$ Department of Orthopaedic and Traumatology, Bakırkoy Sadi Konuk Training and Research Hospital, İstanbul
}

\begin{abstract}
BACKGROUND: Six acute traumatic hip dislocations in pediatric patients were retrospectively analyzed. Types of dislocations, associated lesions, treatment methods, complications, and clinical and radiological outcomes were reviewed.

METHODS: Six child patients treated due to traumatic hip dislocation between 2007 and 2011 in our clinic were included in the study. While five of the patients were male, one was female; the average age was 8 years and 8 months. The mean follow-up was $25.2 \pm 10$ months. There were posterior dislocations in five cases and transepiphyseal fractured dislocation in one case. Four cases were treated by closed reduction while two cases were treated with open reduction method.
\end{abstract}

RESULTS: In the last control of the patients, asymmetric widening in the hip joint was found due to osteochondral fracture in one patient and coxa magna occurred in one patient. Avascular necrosis developed in one case with transepiphyseal fractured dislocation. Harris hip score evaluation was found excellent in five cases and bad in the case with fractured dislocation.

CONCLUSION: Traumatic hip dislocation is a rare condition. It should be treated with preferably closed method as soon as possible. Repetitive reduction trials should be avoided. Open reduction should be performed to recognize accompanying lesions after advanced radiologic examinations such as computerized tomography and magnetic resonance imaging.

Key words: Child; hip dislocation; trauma; treatment.

\section{INTRODUCTION}

Traumatic hip dislocation (THD) is rarely encountered in childhood. Therefore, a lot of series consist small number of patients in the literature. ${ }^{[1-5]}$ Traumatic hip dislocation usually develops as a result of minor trauma. Owing to the elasticity of the periarticular structures in children with THD, associated acetabulum or femoral head fracture is rarer in comparison to adults. ${ }^{[6]}$ Transepiphyseal fractured dislocation is also very rare in children. ${ }^{[7,8]}$

In patients with THD, bad functional and radiologic results

Address for correspondence: Serdar Hakan Başaran, M.D. Karabük Üniversitesi Tıp Fakültesi, Ortopedi ve Travmatoloji Anabilim Dalı, Balıklarkayası Mevkii, 78050 Karabük, Turkey Tel: +90 370 - 4338200 E-mail: drserdarhakan@gmail.com

Qucik Response Code

Ulus Travma Acil Cerrahi Derg

20|4;20(6):437-442

doi: $10.5505 /$ tjtes.2014.52822

Copyright 2014

TJTES may occur due to complications such as femoral head avascular necrosis (AVN) and posttraumatic arthritis. AVN is usually associated with delay in reduction time. ${ }^{[9]}$ Early diagnosis and concentric closed reduction are critical issues in the treatment of THD. If closed reduction cannot be achieved or concentric reduction cannot be obtained, these patients should be treated by open reduction. In addition, open reduction is also the first choice in patients with fracture-dislocation.

Six acute traumatic hip dislocations in pediatric patients were retrospectively analyzed in this study. Types of dislocations, associated lesions, treatment methods, complications, and clinical and radiological outcomes were also reviewed.

\section{MATERIALS AND METHODS}

Six pediatric patients with THD treated in our clinic between 2007 and 2011 were evaluated retrospectively. The collected data included age and sex, type of injury, type of dislocation, associated lesions, the interval between injury and reduction of the dislocation, method of treatment, and complications. The data was collected by computer data and medical charts. Characteristic features of the patients were given in Table I. 
Table I. Characteristic features of the patients

\begin{tabular}{|c|c|c|c|c|c|c|c|c|c|c|}
\hline $\begin{array}{l}\text { Patient } \\
\text { No. }\end{array}$ & $\begin{array}{c}\text { Age } \\
\text { (year, month) }\end{array}$ & Gender & $\begin{array}{l}\text { Trauma } \\
\text { mechanism }\end{array}$ & $\begin{array}{c}\text { Type of } \\
\text { dislocation }\end{array}$ & $\begin{array}{c}\text { Time to } \\
\text { areatment }\end{array}$ & $\begin{array}{l}\text { Associated } \\
\text { lesions }\end{array}$ & $\begin{array}{l}\text { Type of } \\
\text { treatment }\end{array}$ & $\begin{array}{l}\text { Complications } \\
\text { (month) }\end{array}$ & $\begin{array}{c}\text { Follow-up } \\
\text { (HHS) }\end{array}$ & End result \\
\hline I & $6 y, 9 m$ & Female & $\begin{array}{l}\text { Another child } \\
\text { falls on her leg }\end{array}$ & Posterior & 2 hours & & $\begin{array}{l}\text { Closed reduction and } \\
\text { skin traction }\end{array}$ & & 40 & Excellent \\
\hline 2 & $5 y, 9 m$ & Male & Fall at play & Posterior & $\begin{array}{c}2 \text { hours } \\
30 \text { minutes }\end{array}$ & & $\begin{array}{l}\text { Closed reduction and } \\
\text { skin traction }\end{array}$ & & 28 & Excellent \\
\hline 3 & $8 y, 2 m$ & Male & Fall from wall & Posterior & 4 hours & & $\begin{array}{l}\text { Closed reduction and } \\
\text { skin traction }\end{array}$ & & 30 & Excellent \\
\hline 4 & $10 y, 9 m$ & Male & $\begin{array}{l}\text { Fall at playing } \\
\text { football and then } \\
\text { while sleeping }\end{array}$ & Posterior & 8 hours & $\begin{array}{l}\text { Fracture of } \\
\text { acetabular roof } \\
\text { epiphysis and little } \\
\text { bone fragment with } \\
\text { posterior } \\
\text { capsuloligamentous } \\
\text { separation }\end{array}$ & $\begin{array}{l}\text { Open reduction } \\
\text { and spica cast }\end{array}$ & Coxa magna & 25 & Excellent \\
\hline 5 & $9 y, 11 \mathrm{~m}$ & Male & $\begin{array}{l}\text { Another child } \\
\text { falls on his leg }\end{array}$ & Posterior & $\begin{array}{l}3 \text { hours } \\
15 \text { minutes }\end{array}$ & $\begin{array}{l}\text { Osteochondral } \\
\text { fracture of the } \\
\text { posterior acetabular } \\
\text { wall }\end{array}$ & $\begin{array}{l}\text { Closed reduction } \\
\text { and skin traction }\end{array}$ & $\begin{array}{l}3 \mathrm{~mm} \text { joint space } \\
\text { asymmetry }\end{array}$ & 16 & Excellent \\
\hline 6 & $10 y, 11 \mathrm{~m}$ & Male & Hit by car & $\begin{array}{l}\text { Superior- } \\
\text { posterior }\end{array}$ & $\begin{array}{l}16 \text { hours } \\
30 \text { minutes }\end{array}$ & $\begin{array}{l}\text { Transepiphyseal } \\
\text { fracture-dislocation }\end{array}$ & $\begin{array}{l}\text { Open reduction and } \\
\text { hip abduction device }\end{array}$ & $\begin{array}{l}\text { AVN / } \\
\text { Posttraumatic } \\
\text { arthritis }\end{array}$ & 12 & Poor \\
\hline
\end{tabular}

Out of the six patients, five were male and one was female. The mean age at diagnosis was 8 years and 8 months (range, 5 years and 9 months- 10 years and 11 months). The mean follow-up was $25.2 \pm 10$ months (range, 12-40 months). Four cases were applied closed reduction under sedation and analgesia in the emergency room within an average of 2 hours and 57 minutes following dislocation (range, 2-4 hours). THD occurred as a result of low-energy trauma in four patients and high-energy trauma in two.

In five patients, hip dislocations were towards the posterior. Moreover, in a patient with transepiphyseal fractured dislocation, it was superior-posterior. Four patients were treated with closed reduction and two were treated with open reduction. The patients treated with closed reduction were ap- plied bed rest and skin traction after the reduction. In one of the two patients treated with open reduction, spica cast was used and in the other patient, hip abduction device was used. The patients treated with closed reduction were permitted to full weight bearing at the sixth week.

All cases were evaluated clinically and radiologically at the third, sixth, twelfth months, and last follow-up. Harris hip score was used for functional evaluation. Joint space widening of $2 \mathrm{~mm}$ or more was defined as asymmetric enlargement of the hip joint. In comparison to unaffected side, the diameter of the femoral head difference more than $2 \mathrm{~mm}$ was defined as coxa magna.

\section{RESULTS}

Five of the six patients treated with closed reduction had
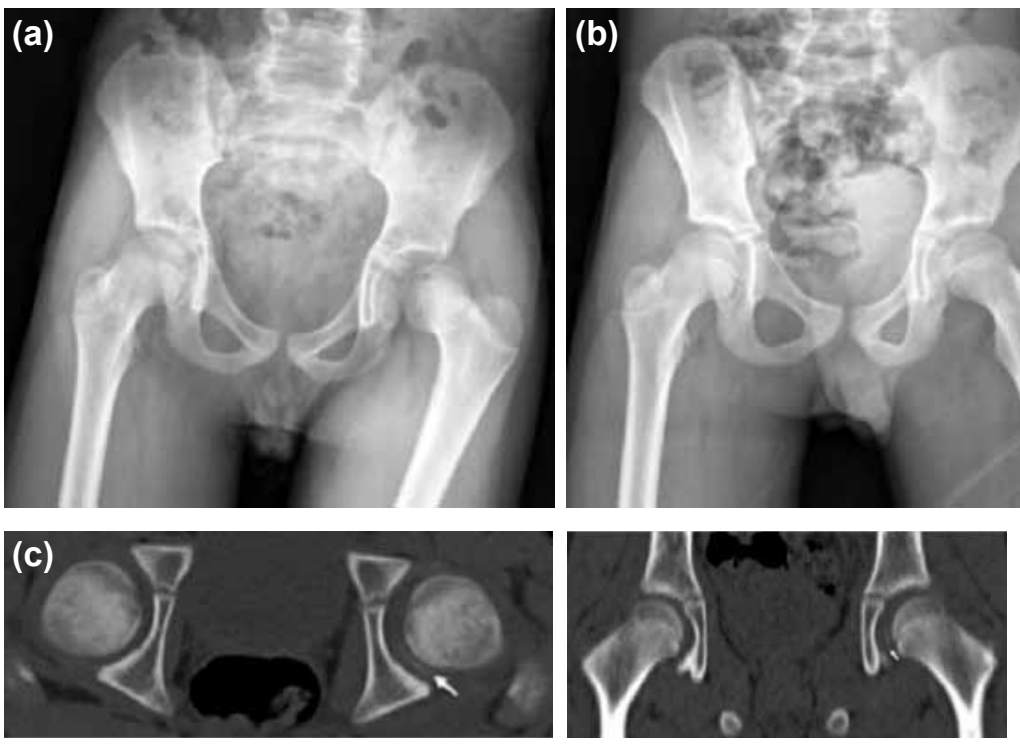

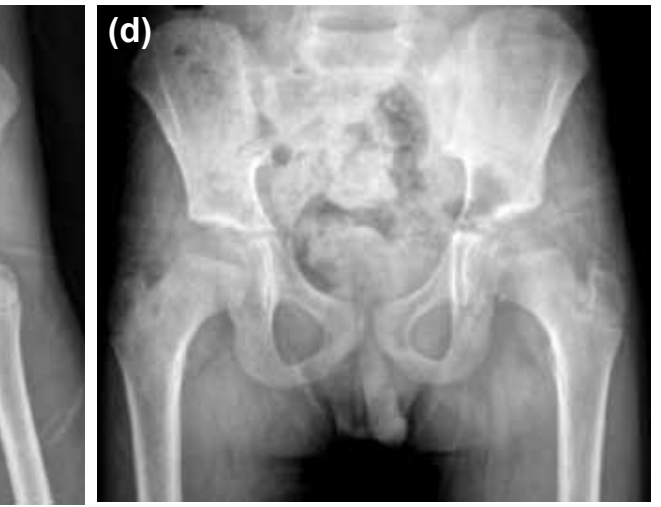

Figure 1. The x-ray image shows posterior hip dislocation (a) and $3 \mathrm{~mm}$ asymmetric enlargement is seen post-reduction x-ray image (b). Osteochondral fracture in the posterior wall of the acetabulum is seen in the CT (c). Asymmetric enlargement in the joint spacing of the same hip continued in the 16 th month X-ray (d). 
painless, full range joint movements and no limping in their last follow-up. They received 100 points from Harris hip score evaluation. None of these cases had sciatic nerve injury or recurrent dislocation.

In the last controls, there were no radiological or clinical leg length discrepancy, heterotrophic ossification, early epiphysis closure, posttraumatic arthritis, and avascular necrosis in five patients. In one patient, there were leg length discrepancy, $\mathrm{AVN}$, and posttraumatic arthritis.

\section{Illustrative Cases}

\section{Case no. I (Patient no. 5)}

A 10-year-old male patient in whom posterior hip dislocation occurred as a result of another child falling down on his affected leg while playing games (Figure la). After closed reduction, $3 \mathrm{~mm}$ asymmetric widening in the hip joint was found compared to the normal side (Figure Ib). The hip was stable during physical examination. Osteochondral fracture in the posterior wall of the acetabulum was seen in post-reduction CT imaging (Figure Ic). The patient was treated with skin traction and bed rest for a month. At the sixteenth month follow-up control, although $3 \mathrm{~mm}$ asymmetric enlargement continued, his hip had full range of motion and was completely painless (Figure Id).

\section{Case no. 2 (Patient no. 4)}

An II-year-old male patient in whose left hip a posterior dislocation developed while sleeping after sports injury (Fig. $2 \mathrm{a})$. Closed reduction was tried under sedation and analgesia in the emergency room at the fourth hour after dislocation, closed reduction was achieved but re-dislocation developed secondary to instability during physical examination. In magnetic resonance (MR) and computerize tomography (CT), torn of capsulolabral complex was seen with apophyseal avulsion fractures from the acetabular edge. By injuring surrounding soft tissues, dislocated femoral head changed the location of superior-posterior (Figure $2 b-d$ ). There was abundant hematoma inside the joint and anterior labrum moved into the joint (Figure 2e). Osteochondral fracture was not determined. The patient was treated by open reduction with posterior approach at the eighth hour. Capsulolabral complex was repaired with absorbable sutures. Pelvipedal plaster cast was applied. Range of motion exercise was started and the patient was allowed to lower extremity partial weight bearing after the plaster was removed at the sixth week. At the twenty-sixth month x-ray control of the patient, $6 \mathrm{~mm}$ coxa magna was seen in the dislocated hip (Figure 2f).

\section{Case no. 3 (Patient no. 6)}

A I0-year and II month-old male patient in whose left hip a transepiphyseal fractured dislocation developed as a result of a traffic accident. It was seen that the fractured femoral head epiphysis moved to superior-posterior in the $\mathrm{X}$-ray and CT image (Figure 3a, b). Open reduction was made by anterior approach at the twelfth hour without attempting closed
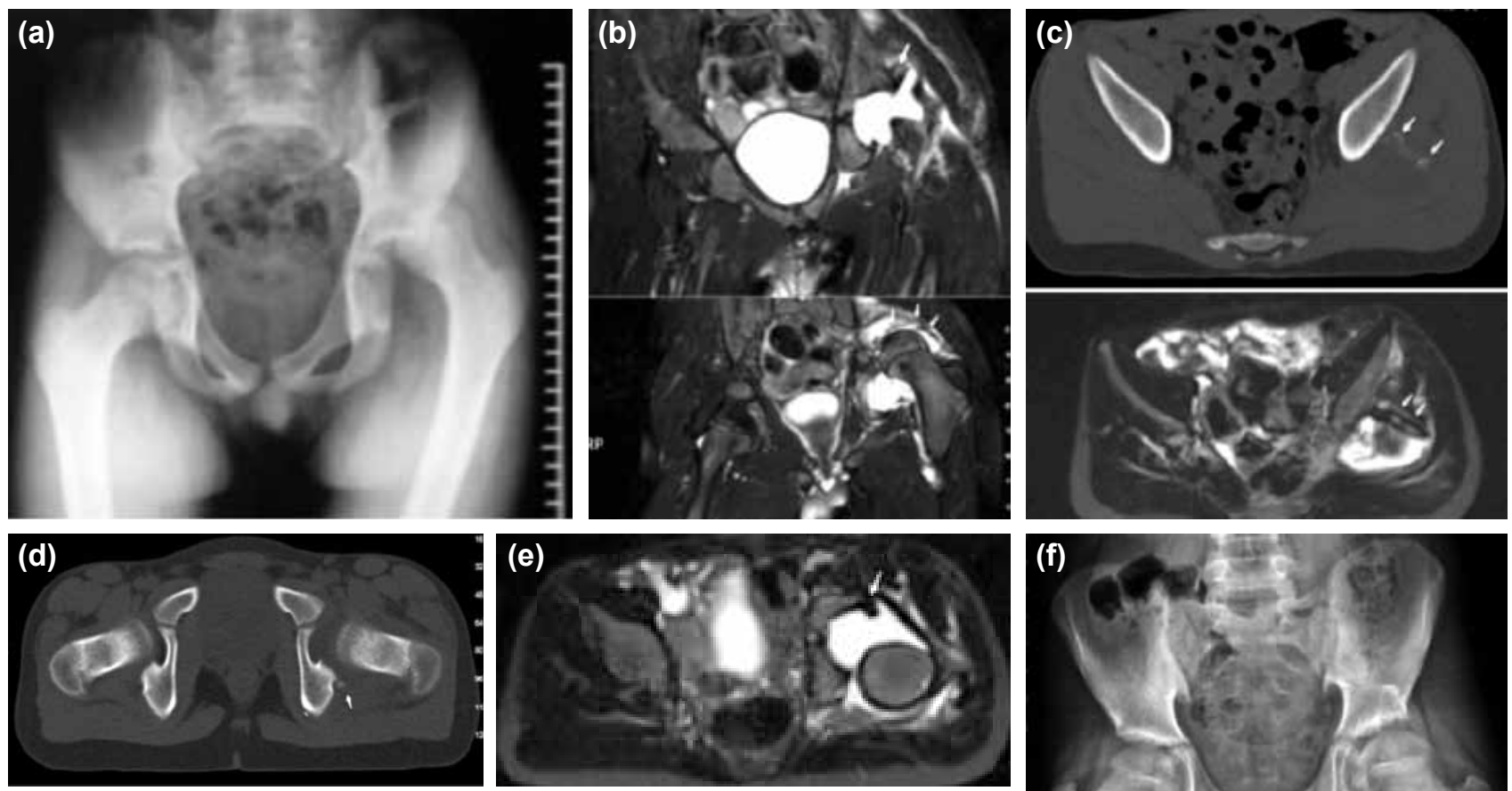

Figure 2. Posterior dislocation is seen in x-ray image (a). In the MR and CT images, it is seen that there are small apophyseal avulsion fractures in the superior and posterior edges of the acetabulum and moving towards to superior-posterior of capsulolabral complex as well as the disruption in the continuance of the joint capsule (b-d). Also, anterior labrum moving into the joint is observed (e). In the last follow-up, $6 \mathrm{~mm}$ coxa magna is seen in the dislocated hip (f).
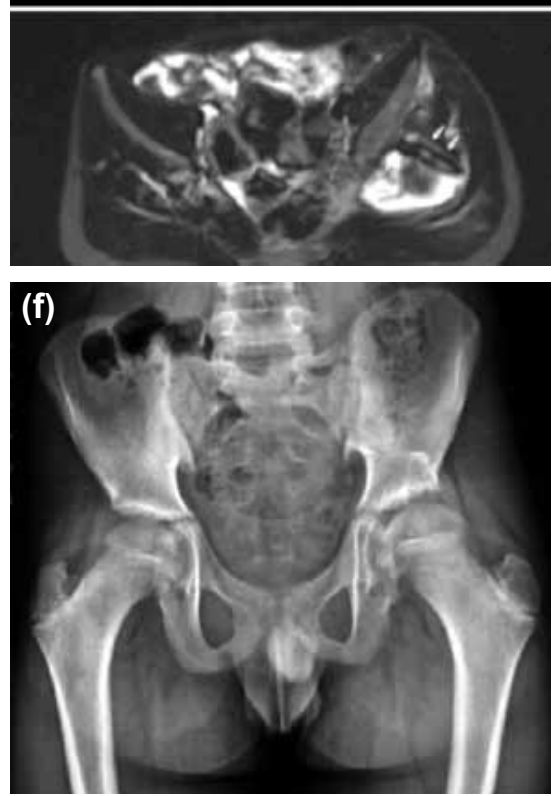

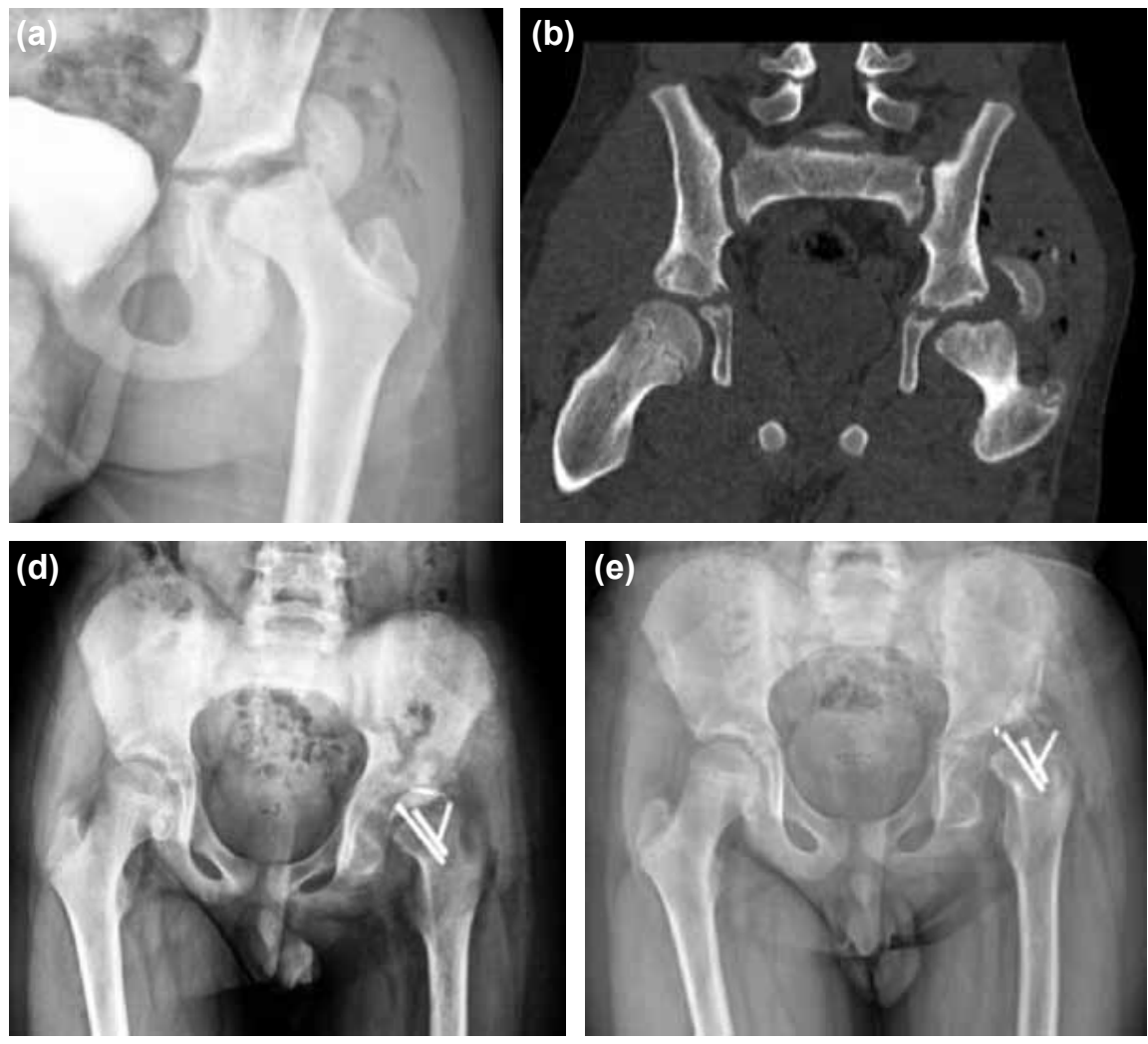

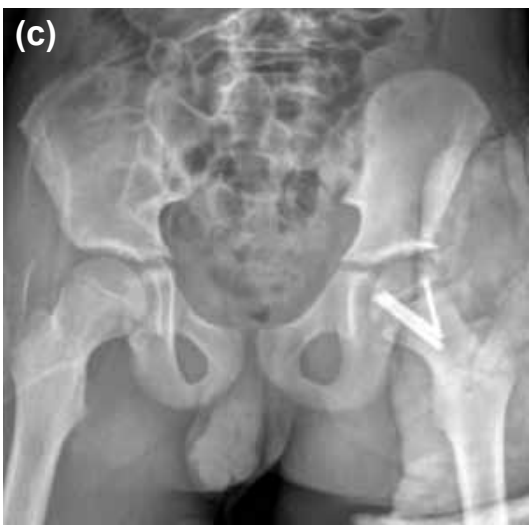

Figure 3. The X-ray (a) and CT (b) images show transepiphyseal fractured dislocation in the left hip as well as the femoral head epiphysis moving towards superior-posterior direction. Postoperative X-ray image (c). In the third month X-ray image, AVN is seen in the femoral head (d), and posttraumatic arthritis and subluxation is seen in the first year control X-ray (e). reduction. After the transepiphyseal fracture had been fixed by three retrograde Herbert screws, the hip was reduced. Injured capsulolabral complex was repaired with anchor suture (Figure 3c). Patient's hip was stabilized with hip abduction device for two months. He was permitted to walk with partial weight bearing at the eighth week and full weight bearing in the tenth. At the third month follow-up, AVN occurred in the femoral head (Figure 3d). Posttraumatic arthritis and subluxation were determined at the first year follow-up (Figure 3e). Furthermore, there were $1.5 \mathrm{~cm}$ leg length discrepancy and restriction and pain in his hip movements. Harris hip score of this case was $6 \mathrm{I}$.

\section{DISCUSSION}

Traumatic hip dislocation is a rare condition with a bad prognosis due to potential complications in children. THD usually occurs as a result of low energy traumas such as simple falls and sport injuries in children under the age of ten. ${ }^{[1,10-13]}$ Higher energy traumas such as falls from height and traffic accidents are prominent in children over the age of ten. ${ }^{[14,15]}$ THD is classified as anterior, posterior, central and inferior. It is three to four times more frequently encountered in boys than girls. ${ }^{[5,16-18]}$ Posterior dislocations are much more frequent than anterior dislocations similar to the adult age group. ${ }^{[5,6,14,19]}$ Our findings were consistent with the literature.

The main treatment modality is closed reduction of the THD under sedation or general anesthesia as soon as possible, preferably within the first six hours..$^{[9,16,19-21]}$ If THD cannot be reduced by closed method, open reduction should be performed. However, open reduction may cause additional vascular injury leading to AVN and posttraumatic arthritis ${ }^{[16]}$. After closed reduction, the hip should be evaluated for its stability by physical examination and concentric reduction should be confirmed by $\mathrm{X}$-ray imaging.

Concentric reduction may not be obtained due to intraarticular osteochondral lesion and massive hematoma, as well as incarceration of the muscles, tendons, torn capsulolabral complex, and ligamentum teres. ${ }^{[18,22,23]}$ Although bone and osteochondral lesions are better evaluated with CT, MRI is more superior for evaluating trapped soft tissues in the joint, as well as capsular lesions and surrounding muscle and tendinous structures. Especially, if concentric reduction cannot be provided in older children, osteochondral fracture should be kept in mind. ${ }^{[17,18]}$ In their study, Mehlman et al. ${ }^{[16]}$ had not encountered any radiological or functional sequel in four patients with up to $6 \mathrm{~mm}$ asymmetric joint enlargements after closed reduction. Vialle et al. ${ }^{[1]}$ had not determined any correlations between the severity of trauma and soft tissue entrapment or osteochondral fracture in their study. In our study, osteochondral fracture was encountered in only one patient as a result of low energy trauma.

THD complications are much rarely encountered in children than adults except for recurrent dislocation. ${ }^{[6,20,24,25]}$ Recurrent dislocation usually develops based on a defect or joint capsule laxity. In the literature, recurrent dislocations are more com- 
monly seen especially in children with two weeks or and less immobilization or allowed early ambulation. ${ }^{[2,25]}$ None of our cases developed recurrent dislocation. Thus, it is our belief that in children under the age of ten, immobilization for four weeks along with suitable rehabilitation is particularly important for the healing of surrounding soft tissues to make the joint become stable.

In children, THD may also lead to complications such as femoral head avascular necrosis, sciatic nerve palsy, posttraumatic degenerative arthritis, and coxa magna. Recent studies have reported that the sciatic nerve palsy is the most common complication. In the literature, sciatic nerve palsy has been found between $5 \%$ and $20 \% .{ }^{[14,19]}$ However, among all complications, AVN has the worst prognosis. ${ }^{[12,14,19]}$

The velocity of trauma, age at the time of injury, the interval between initial trauma and reduction, and fractured dislocation have been emphasized as predisposing factors in the development of $A V N{ }^{[9,13,21,26]}$ The possibility of AVN increases in older children ${ }^{[1,6,12]}$ High energy trauma also increases the risk of AVN development. ${ }^{[3,9]}$ AVN usually develops in the first three years. ${ }^{[14,19]}$ In the literature, AVN rate has been reported $3-15 \%$ in patients whose reduction has been performed in six hours. AVN rate reaches up to $100 \%$ in neglected THD patients ${ }^{[9,13,15-17,19,27]}$ However, recent studies have found that AVN rate is less than $5 \% .^{[12,17]}$ Additionally, AVN rate has been reported $80-100 \%$ in children with fractured dislocation. ${ }^{[9,28-}$ ${ }^{30]} \mathrm{AVN}$ developed in none of the patients with isolated hip dislocation in this study.

Growth disturbance develops due to proximal femoral physis damage and affects especially children under the age of 12 and it may lead to leg length discrepancy and angular deformities in the femoral neck. ${ }^{[9]}$ Growth disturbance usually emerges as coxa magna in children older than 12 years. Physeal damage can be directly related to trauma and it may also occur due to fracture, AVN, synovitis, and reactive hyperemia. ${ }^{[13,15]}$ Coxa magna was encountered in only one patient in the present study.

Posttraumatic arthritis usually develops nearly four years after the trauma and is usually associated with avascular changes and intraarticular fractures. ${ }^{[6,14,24]}$ Radiological changes in these patients emerge much later. Radiologic arthritic findings appeared in a patient in this study in the first year due to intraarticular penetration of the fixation materials and development of $\mathrm{AVN}$. Retrograde fixation is not recommended because of its difficult removal and risk of joint penetration. It is our opinion that anchor suture in the acetabular edge does not provide sufficiently stabile fixation in pediatric cases, and therefore, it should not be used close to the joint.

General opinion is to allow partial weight bearing of patients at the fourth or sixth weeks and then pass onto full load.
$[1,2,6,16,20]$ Prolonged immobilization and no weight bearing of the affected leg do not decrease AVN incidence and severity. ${ }^{[9,21]}$ A similar treatment protocol was applied in our cases. Functional results of the patients with THD are usually very good. ${ }^{[2,3,16-18]}$ In contrast, poor results are often related to accompanying injuries and AVN. However, functional results have been found good in the majority of the patients with AVN. ${ }^{[17,18,25]}$ The limitations of the present study were small number of patients and short follow-up period.

Especially in children, THD should be diagnosed rapidly and must be treated urgently. Repetitive closed reduction trials should be avoided. If it is not possible to obtain a stable closed reduction, advanced imaging techniques such as CT and MRI should be carried out for investigating prohibitive causes. If closed reduction is not successful, open reduction should be considered. It should be kept in mind that the rate of avascular necrosis may reach up to $100 \%$ in cases with transepiphyseal fracture accompanied by dislocation.

\section{Conflict of interest: None declared.}

\section{REFERENCES}

1. Kutty S, Thornes B, Curtin WA, Gilmore MF. Traumatic posterior dislocation of hip in children. Pediatr Emerg Care 2001;17:32-5. CrossRef

2. Gürkan V, Dursun M, Orhun H, Sever GB, Kiliçkap C, Berkel T. Evaluation of pediatric patients with traumatic hip dislocation. Acta Orthop Traumatol Turc 2006;40:392-5.

3. Zrig M, Mnif H, Koubaa M, Abid A. Traumatic hip dislocation in children. Acta Orthop Belg 2009;75:328-33.

4. Kural C, Bayraktar K, Ertürk A, Ertürk H. Çocuklarda travmatik kalça çıkı̆ı: iki olgu sunumu. Joint Dis Rel Surg 2006;17:49-52

5. Freeman GE Jr. Traumatic dislocation of the hip in children: A report of 7 cases and review of the literature. J Bone Joint Surg Am 1961;43:401-6.

6. Salisbury RD, Eastwood DM. Traumatic dislocation of the hip in children. Clin Orthop Relat Res 2000;377:106-11. CrossRef

7. Mohammad S, Port A, Montgomery RJ. Transepiphyseal fracture of the femoral neck with dislocation of the femoral head and fracture of the posterior column of the acetabulum in a child. J Bone Joint Surg Br 2002;84:113-5. CrossRef

8. Akahane T, Fujioka F, Shiozawa R. A transepiphyseal fracture of the proximal femur combined with a fracture of the mid-shaft of ipsilateral femur in a child: a case report and literature review. Arch Orthop Trauma Surg 2006;126:330-4. CrossRef

9. Barquet A. A vascular necrosis following traumatic hip dislocation in childhood: factors of influence. Acta Orthop Scand 1982;53:809-13.

10. Barquet A. Traumatic anterior dislocation of the hip in childhood. Injury 1982;13:435-40. CrossRef

11. Rieger H, Pennig D, Klein W, Grünert J. Traumatic dislocation of the hip in young children. Arch Orthop Trauma Surg 1991;110:114-7. CrossRef

12. Hamilton PR, Broughton NS. Traumatic hip dislocation in childhood. J Pediatr Orthop 1998;18:691-4. CrossRef

13. Barquet A. Traumatic hip dislocation in childhood. A report of 26 cases and review of the literature. Acta Orthop Scand 1979;50:549-53. CrossRef

14. Pearson DE, Mann RJ. Traumatic hip dislocation in children. Clin Orthop Relat Res 1973;92:189-94. CrossRef

15. Offierski CM. Traumatic dislocation of the hip in children. J Bone Joint 
Surg Br 1981;63-B:194-7.

16. Mehlman CT, Hubbard GW, Crawford AH, Roy DR, Wall EJ. Traumatic hip dislocation in children. Long-term followup of 42 patients. Clin Orthop Relat Res 2000;376:68-79. CrossRef

17. Vialle R, Odent T, Pannier S, Pauthier F, Laumonier F, Glorion C. Traumatic hip dislocation in childhood. J Pediatr Orthop 2005;25:138-44.

18. Vialle R, Pannier S, Odent T, Schmit P, Pauthier F, Glorion C. Imaging of traumatic dislocation of the hip in childhood. Pediatr Radiol 2004;34:970-9. CrossRef

19. Hougaard K, Thomsen PB. Traumatic hip dislocation in children. Follow up of 13 cases. Orthopedics 1989;12:375-8.

20. Nirmal Kumar J, Hazra S, Yun HH. Redislocation after treatment of traumatic dislocation of hip in children: a report of two cases and literature review. Arch Orthop Trauma Surg 2009;129:823-6. CrossRef

21. Schlonsky J, Miller PR. Traumatic hip dislocations in children. J Bone Joint Surg Am 1973;55:1057-63.

22. Burgos J, Gonzalez-Herranz P, Ocete G. Traumatic hip dislocation with incomplete reduction due to soft-tissue interposition in a 4-year-old boy. J Pediatr Orthop B 1995;4:216-8. CrossRef
23. Slätis P, Latvala A. Irreducible traumatic posterior dislocation of the hip. Injury 1974;5:188-93. CrossRef

24. Thompson VP, Epstein HC. Traumatic dislocation of the hip; a survey of two hundred and four cases covering a period of twenty-one years. J Bone Joint Surg Am 1951;33:746-78.

25. Muratli HH, Dağli C, Biçimoğlu A, Tabak AY. Recurrent traumatic hip dislocation in a child. Acta Orthop Traumatol Turc 2004;38:149-53.

26. Barquet A. Natural history of avascular necrosis following traumatic hip dislocation in childhood: a review of 145 cases. Acta Orthop Scand 1982;53:815-20. CrossRef

27. Banskota AK, Spiegel DA, Shrestha S, Shrestha OP, Rajbhandary T. Open reduction for neglected traumatic hip dislocation in children and adolescents. J Pediatr Orthop 2007;27:187-91. CrossRef

28. Walls JP. Hip fracture-dislocation with transepiphyseal separation. Case report and literature review. Clin Orthop Relat Res 1992;284:170-5.

29. Canale ST, Bourland WL. Fracture of the neck and intertrochanteric region of the femur in children. J Bone Joint Surg Am 1977;59:431-43.

30. Werkman DM. The transepiphyseal fracture of the femoral neck. Injury 1980;12:50-2. CrossRef

\section{OLGU SERISII - ÖZET}

\section{Pediatrik travmatik kalça çıkığı tedavi ve sonuçları: Olgu çalışması ve literatürün gözden geçirilmesi}

\section{Dr. Serdar Hakan Başaran, ${ }^{1}$ Dr. Mustafa Gökhan Bilgili, ${ }^{2}$ Dr. Ersin Erçin, ${ }^{2}$} Dr. Alkan Bayrak, ${ }^{2}$ Dr. Halil Nadir Öneş, ${ }^{2}$ Dr. Mustafa Cevdet Avkan ${ }^{2}$

${ }^{1}$ Karabük Üniversitesi Tıp Fakültesi, Ortopedi ve Travmatoloji Anabilim Dalı, Karabük;
${ }^{2}$ Bakırköy Dr. Sadi Konuk Eğitim ve Araştırma Hastanesi, Ortopedi ve Travmatoloji Kliniği, İstabul

AMAÇ: Akut travmatik kalça çıkığı olan altı çocuk hasta geriye dönük olarak incelendi. Bu hastalarda çıkığın tipi, ilişkili lezyonlar, tedavi yöntemleri, komplikasyonlar, klinik ve radyolojik sonuçlar değerlendirildi.

GEREÇ VE YÖNTEM: Kliniğimizde 2007 ile 201 I tarihleri arasında travmatik kalça çıkığı nedeniyle tedavi edilmiş olan altı çocuk hasta çalışmaya alındı. Hastaların beşi erkek, biri kız, ortalama yaş 8 yıl 8 ay (dağılım; 5 yıl 9 ay- 10 yıl II ay). Olguların ortalama takip süreleri $25.2 \pm 10$ aydı. (dağıım I2-40 ay). Beş olguda posterior çıkık, bir olguda ise transepifizyal kırıklı çıkık mevcuttu. Dört olgu kapalı, iki olgu ise açık redüksiyon yöntemiyle tedavi edildi.

BULGULAR: Hastaların son takibinde, bir hastada osteokondral kırığa bağlı eklem mesafesinde asimetrik genişleme saptandı, diğer bir hastada koksa magna gelişti. Transepifizyal kırıklı çıkığı olan bir olguda avasküler nekroz gelişti. Beş olguda Harris hip skoru değerlendirmesi mükemmel, kırıklı çıkık olgusunda ise kötü olarak bulundu.

TARTIŞMA: Bu oldukça nadir karşılaşılan olgular mümkün olan en kısa sürede öncelikle kapalı yöntemle tedavi edilmelidir. Tekrarlayan kapalı redüksiyon denemelerinden kaçınımalı, redükte olmayan olgularda eşlik eden lezyonların önceden tanınması için mümkünse BT ve MR görüntüleme gibi ileri incelemeler yapıldıktan sonra açık redüksiyona geçilmelidir.

Anahtar sözcükler: Çocuk; kalça çıkı̆̆; tedavi; travma.

Ulus Travma Acil Cerrahi Derg 20।4;20(6):437-442 doi: 10.5505/tjtes.20।4.52822 